\title{
Reading prosody in Spanish dyslexics
}

\author{
Paz Suárez-Coalla ${ }^{1}$ - Marta Álvarez-Cañizo ${ }^{1}$. \\ Cristina Martínez ${ }^{1}$ - Noemí García ${ }^{1}$ - Fernando Cuetos ${ }^{1}$
}

Received: 6 September 2015 / Accepted: 11 January 2016

(C) The International Dyslexia Association 2016

\begin{abstract}
Reading becomes expressive when word and text reading are quick, accurate and automatic. Recent studies have reported that skilled readers use greater pitch changes and fewer irrelevant pauses than poor readers. Given that developmental dyslexics have difficulty acquiring and automating the alphabetic code and developing orthographic representations of words, it is possible that their use of prosody when reading differs from that of typical readers. The goal of this study was to investigate whether the reading prosody of Spanish-speaking dyslexics differs from that of typical Spanish readers. Two experiments were performed. The first experiment involved 36 children (18 with dyslexia), and the second involved 46 adults (23 with dyslexia). Participants were asked to read aloud a text which included declarative, exclamatory and interrogative sentences. Data on pausing and reading rate (number of pauses, duration of pauses and utterances), pitch changes, intensity changes and syllable lengthening were extracted from the recordings. We found that dyslexic people read more slowly than typical readers and they also made more inappropriate and longer pauses, even as adults with considerable reading experience. We also observed that dyslexics differed from skilled readers in their use of some prosodic features, particularly pitch changes at the end of sentences. This is probably because they have trouble anticipating some structural features of prose, such as sentence ends.
\end{abstract}

Keywords Dyslexia $\cdot$ Fundamental frequency $\cdot$ Pausing $\cdot$ Prosody $\cdot$ Spanish $\cdot$ Text reading

\section{Introduction}

Prosody is an integral part of speech and has an important role in oral communication; it is used by speakers to direct listeners' attention, to emphasise certain words, phrases and ideas and to disambiguate sentences (Choi, 2003; Goldman-Eisler, 1968; Grosjean, Grosjean, \&

Paz Suárez-Coalla

suarezpaz@uniovi.es

1 Department of Psychology, University of Oviedo, Pza Feijoo s/n, 33003 Oviedo, Asturias, Spain 
Lane, 1979). Prosodic parameters such as pitch (fundamental frequency: $F_{0}$ ), pausing, intensity and syllable lengthening are used in various ways by speakers to help them achieve their communication aims.

Prosody also plays an important role in reading; expressiveness is considered an indicator of reading ability and a part of reading fluency (Cowie, Douglas-Cowie, \& Wichmann, 2002; Benjamin \& Schwanenflugel, 2010; Miller \& Schwanenflugel, 2006, 2008; Schwanenflugel, Hamilton, Kuhn, Wisenbaker, \& Stahl, 2004) since non-fluent readers have a flattened intonation when reading aloud (Kuhn, Schwanenflugel, \& Meisinger, 2010). There is no clear consensus on how the term 'fluency' should be defined (cf. Kame'enui \& Simmos, 2001; LaBerge \& Samuels, 1974; Logan, 1997; National Institute of Child Health and Human Development, 2000; Perfetti \& Hogaboam, 1975; Pikulski \& Chard, 2005). It has been defined, in a very simple way, making reference to the rate and accuracy of oral reading (Logan, 1997), but more recent theoretical models have extended the concept of fluency to include dimensions such as prosody or expressive oral reading (Kame'enui \& Simmos, 2001; National Institute of Child Health and Human Development, 2000; Pikulski \& Chard, 2005; Schwanenflugel et al., 2006; Wolf \& Katzir-Cohen, 2001). The National Reading Panel of the USA (NICHD, 2000) suggested that fluency in oral reading is manifested in high levels of accuracy, rate and expressiveness (or prosody) and also asserted that fluency implies an ability to make speedy use of punctuation and knowledge of where to place emphases or pauses to give meaning to the text. Similarly, Pikulski and Chard (2005) proposed that fluency manifests as accurate, rapid and expressive oral reading. Otherwise, Wolf and Katzir-Cohen (2001) suggested that fluency is multi-dimensional, as it depends on perceptual, phonological, orthographical and morphological processing. They added that fluent reading requires the child automatically to integrate phonics and spelling knowledge in order to recognise entire words and to link recognised words to make natural phrases, using appropriate enunciation and emphasis. These definitions suggest that word recognition skills and prosodic reading are closely related and that expressive reading depends on the ability to read quickly and accurately.

Some prosodic features seem to be universal, although they are sometimes modulated by other variables such as focus, dialectal variation and emotional state. Common prosodic features include a decrease in pitch across a phrase; a long pitch rise in the first syllables of the sentence; repetition of pitch rises (peaks) and falls (valleys), a cycle that delimits a prosodic unit; and the lengthening of the last syllables of a phrase (pre-pausal elongation), accompanied by a decrease in intensity (Martínez-Celdrán \& Fernández-Planas, 2013; Vaissière, 1983). Considering the Spanish language and the sentence type (declarative, interrogative and exclamatory), in declarative sentences, the voice tends to show a decrease in pitch in the final segment of the sentence, and a general decline in pitch throughout the sentence; the final falling inflexion is the most common feature of exclamatory phrases. It has been reported that there is a rise in pitch in the final part of yes-no questions, in addition to a marked rise in pitch around the first stressed syllable, whereas wh-questions seem to be characterised by a rise in pitch around the first stressed syllable and, frequently, by a decrease in pitch at the end of the sentence (Baqué \& Estruch, 2003; Garrido, 1990). In general, prosodic patterns in reading appear to be similar to those of oral language; however, the development of prosodic reading might be influenced by the orthographic transparency of the written system concerned, as it is known that accurate reading emerges earlier in transparent orthographies than opaque orthographies. In addition, in written Spanish (unlike English), an orthographic mark is placed at the beginning of interrogative and exclamatory sentences as well as at the end (e.g. ¡Qué gran 
noticia! [What a great notice!] or ¿Qué hora es? [What time is it?]). This is important as the orthographic mark at the beginning of sentences might help the reader to plan the prosody; however, from a developmental perspective, it is important to note that it is not clear that children understand and use these orthographic marks appropriately (Schwanenflugel, Westmoreland, \& Benjamin, 2013).

It is widely recognised that intonation is closely linked to reading comprehension. Many studies have demonstrated that children with adult-like intonation contours usually have good reading comprehension (Calet, Defior, \& Gutiérrez-Palma, 2013; Fuchs, Fuchs, Hosp, \& Jenkins, 2001; Klauda \& Guthrie, 2008; Miller \& Schwanenflugel, 2006; Ravid \& Masharaki, 2007; Miller \& Schwanenflugel, 2008; Rasinski, Rikli, \& Johnston, 2009). In a study conducted with third-grade children (mean age $=9$ years 3 months), Miller and Schwanenflugel (2006) found that use of pitch changes (the decrease across declarative sentences and the rise at the end of 'yes-no' questions) was associated with reading comprehension ability, whereas pausing was related to decoding ability (the ability to translate graphemes into sound). Ravid and Mashraki (2007) described a similar relationship between prosody and comprehension in 9- and 10-year-old Hebrew children; fluent and expressive readers showed good comprehension. It was found that for Spanish, the relationship between prosody and comprehension varied across grades, with intonation being the best predictor of comprehension in grade 4 (Calet et al., 2013). However, the direction of the relationship between reading prosody and comprehension is unclear. According to some authors, reading prosody improves comprehension because prosodic rendering allows text to be segmented along syntactic and semantic boundaries (Cromer, 1970; Kuhn \& Stahl, 2003; O'Shea \& Sindelar, 1983) or the syntactic role of the different elements may be correctly assigned (Chafe, 1988). Koriat, Greenberg, and Kreiner (2002) speculated that good readers are able to generate the prosody of a sentence from structural cues and that prosodic contouring plays an important role in maintaining the early structural analysis in working memory, whilst comprehension analyses are performed (hypothesis of structural precedence). In contrast, prosody may also be viewed as a consequence of reading comprehension: the segmentation of text into phrases using the appropriate prosody indicates that the reader understands the text (Ravid \& Mashraki, 2007).

Taking into consideration the literature revised and given that developmental dyslexia is characterised by persistent reading difficulties, it is possible to expect that children with developmental dyslexia may show deficits in use of intonation when reading text. In recent years, reading problems in dyslexia have been investigated in numerous different orthographies (English, Spanish, French, German, etc.) (Barca, Burani, Di Filippo, \& Zoccolotti, 2006; Grainger, Bouttevin, Tuc, Bastien, \& Ziegler, 2003; Rack, Snowling, \& Olson, 1992; SuárezCoalla \& Cuetos, 2012; Wimmer, 1993; Ziegler, Perry, Ma-Wyatt, Ladner, \& Schulte-Korne, 2003), and these studies have shown that dyslexic reading is characterised by excessive slowness and inaccuracy. The research also suggests that people with dyslexia have difficulty acquiring and automating the alphabetic code, as well as having difficulty in developing orthographic representations of words (Ehri \& Saltmarsh, 1995; Manis, 1985; Reitsma, 1983; Suárez-Coalla, Ramos, Álvarez-Cañizo, \& Cuetos, 2014; Suárez-Coalla \& Cuetos, 2015), and it seems that, as a consequence, their reading remains tied to a sub-lexical procedure, which impedes development of smooth and fluent reading.

Accuracy and reading speed in the dyslexic population have received considerable research attention (Grainger et al., 2003; Rack et al., 1992; Wimmer, 1993; Ziegler et al., 2003); however, it is unknown to what extent dyslexic reading is expressive in the standard sense 
and to what extent their prosody differs from that of non-dyslexic readers. To date, few studies have investigated reading fluency and prosody in dyslexia (Alves, Reis, \& Pinheiro, 2015; De Luca, Pontillo, Primativo, Spinelli, \& Zoccolotti, 2013; Suárez-Coalla \& Cuetos, 2015). In a study of 16 dyslexic readers (aged 11 and 12 years old) and 16 age-matched typical readers, De Luca et al. (2013) found that dyslexic readers produced frequent, long pauses when reading a text. Similar results were reported by Suárez-Coalla and Cuetos (2015), when reading aloud dyslexic Spanish adults with post-secondary education or a university degree spent more time pausing and paused more frequently than controls. The authors argued that in adulthood, people with dyslexia continued to read more slowly than typical readers, probably owing to problems with integration of phonological and orthographic codes, i.e. failure to synchronise orthographic identification and the phonological representation (Breznitz \& Misra, 2003; Meyler \& Breznitz, 2003). According to this interpretation, dyslexic adults have orthographic and phonological representations of words but find it difficult to coordinate them when reading; hence, reading is slower.

Alves et al. (2015) compared temporal and prosodic parameters in 9-year-old Portuguese dyslexic and control children. They measured $F_{0}$ for stressed vowels and pre-stressed vowels to estimate the speed of melodic movement. They found that regardless of the frequency and duration of their pauses during reading, dyslexics demonstrated limited melodic variation and had difficulty producing typical stress patterns.

It has also been reported that adults with low literacy skills (word decoding problems) differ from skilled readers with respect to some prosodic parameters (Binder, Tighe, Jiang, Kaftanski, Qi, \& Ardoin, 2013). Binder et al. (2013) examined final pitch decreases and pitch variability in declarative sentences and final pitch increase in wh-question sentences; they found that lowliteracy adults made more pauses than typical readers and showed no pitch change in whquestions. Schwanenflugel et al. (2004) reported that skilled readers (second and third graders, aged from 7 years 4 months to 10 years 4 months) made shorter pauses within and between sentences than less skilled readers. These studies suggest that expressiveness emerges as reading skills improve (i.e. speed and accuracy increase) and that fluent readers make greater pitch changes and fewer irrelevant pauses than less fluent readers.

The studies of typical and atypical readers discussed above mainly relate to reading prosody in English speakers (exception of described work in Portuguese, Italian and Spanish), and the reading prosody of Spanish speakers might be different, given the consistency of the Spanish orthographic system and the use of orthographic marks at the beginning of the interrogative and exclamatory sentence.

The aim of this study was to determine whether there are differences between the reading prosody of Spanish dyslexic and typical readers. In the first experiment, we compared the oral reading of a group of dyslexic children and typical readers (matched for age, gender and education). Groups of dyslexic adults and skilled readers participated in a second experiment, which investigated the reading prosody in dyslexics with many years of reading experience. Data on several prosodic features such as pitch changes, intensity, pausing and the durations of syllables and utterances were collected.

Based on previous research into reading difficulties in dyslexia and reading prosody, we predicted that dyslexic readers would spend more time pausing and produce more inappropriate pauses than typical readers. We also predicted that there would be differences in use of prosodic cues. Specifically, given the prosodic features of Spanish, we expected to find that when reading declarative sentences, dyslexic readers would show a shallower pitch gradient, a smaller pitch rise at the beginning of the sentence and a small fall in pitch at the end of the 
sentence than control readers. We also expected dyslexic readers to have difficulty managing the pitch rise at the beginning of these types of sentence (indicated by the orthographic marks i or $i)$. Finally, we expected dyslexic readers to show a smaller decrease in pitch at the end of wh-questions and a smaller rise in pitch at the end of yes-no questions. We considered that such difficulties were a probable consequence of impairments in word recognition and structural processing.

\section{Experiment 1}

\section{Materials and methods}

Participants Thirty-six native Spanish-speaking children (third to sixth grade, aged from 8 to 12 years $)$ participated in this study: 18 children with dyslexia $\left(M_{\text {age }}=9.61\right.$ years, $\left.\mathrm{SD}=1.75\right)$ and 18 age-matched children without reading problems $\left(M_{\text {age }}=9.66\right.$ years, $\left.\mathrm{SD}=1.61\right)$. Both groups consisted of 5 boys and 13 girls, and they had similar sociocultural backgrounds (middle class); none of the participants had a known cognitive impairment. Third graders were included because at this age, Spanish children are considered to have a good reading level, allowing them to read a connected text (Cuetos \& Suarez-Coalla, 2009), and it has been reported that second-grade children (7-8 years old) develop adult-like intonation contours (Miller \& Schwanenflugel, 2008).

The dyslexic participants were receiving individualised treatment at a speech therapy centre or special attention in their school. Dyslexia was diagnosed on the basis of a battery of assessments of reading processes, PROLEC-R (Cuetos, Rodríguez, Ruano, \& Arribas, 2007) and the Spanish version of the Wechsler Intelligence Scale (Wechsler, 2001). The reading battery includes tasks designed to evaluate all the processes involved in reading: letter identification (to evaluate letter knowledge), including 20 letters to name as quickly and accurately as possible; lexical and sub-lexical processing, where a list of 40 words varying in length, frequency and syllabic structure and a list of 40 pseudowords are included; syntactic processing, task that allows to assess the comprehension of different types of syntactic structures; and reading comprehension, where literal and inferential questions are used to evaluate understanding of narrative and expository texts. Decoding ability and word recognition ability were inferred from speed and accuracy in the reading of words and pseudowords. Based on performance in lexical and sub-lexical processing, all participants from the dyslexic group showed levels of reading accuracy and speed, between 1.5 and $2 \mathrm{SD}$, below the average for their age. Otherwise, the mean IQ for the dyslexic group was 105 (range 90 to 120).

Control children attended a monolingual public school that served children from early childhood ( 3 years old) to sixth grade (12 years old). The school had an academic advisor who evaluated the children for all kinds of learning difficulties. The school also had a special education teacher and a speech therapist who worked with children with difficulties. None of the children who participated in this study had learning difficulties, and based on PROLEC-R, their reading level was appropriate to their age. Control children were selected in every classroom (by choosing a number from the list of class group), after exclusion of children with specific difficulties.

There was a difference between the reading scores of the dyslexic and control groups (see Table 1). 
This research was approved by the Ethics Committee of the Psychology Department, University of Oviedo. The children's parents were given information about the purpose of the study and the tasks involved. All parents provided written, informed to their children's participation in advance.

Material A 289-word text entitled 'El Gigante Egoísta [The Selfish Giant]' (an adaptation of the story by Oscar Wilde) was used. This text was selected because the story was expected to be interesting to the children; however, the original story was modified to reduce its length and introduce the sentences required for the experiment. Various readability parameters for the text were calculated using two programs: INFLESZ and FLESH. The FLESH programme provided two scores: Flesch-Kincaid Grade Level (index of the years of education required to comprehend a document) and Flesch Reading Ease Score (an index of the difficulty of comprehension of a document; range $0-100$, where 100 indicates an extremely simple document, 0 a very complex document). Both scores are calculated based on the number of sentences, words and syllables contained in a text. The INFLESZ programme also provided two indices: Flesh-Szigriszt score (similar to Flesch Reading Ease Score; Szigriszt-Pazos, 1993) and Flesh Fernández-Huerta score (adaptation by Fernández-Huerta, 1959). The readability parameters for our experimental text were as follows: Flesh-Kincaid Grade Level=7.93, Flesh Reading Ease Score $=63.19$, Flesh-Szigriszt score $=79.54$ and Flesh FernándezHuerta score $=83.76$. The text was presented on a paper in double-spaced 12-point, Times New Roman font. Children were tested individually in a separate room; dyslexic children were tested in the speech therapy centre and control children in their school. The children were not given an opportunity to read the text silently before commencing the reading aloud task. Reading was recorded using a SONY ICD-UX533 recorder (sampling frequency $44.1 \mathrm{kHz}$ ), and audio recordings were processed offline using Praat software.

Table 1 Demographic characteristics, means and standard deviations for reading scores of control and dyslexic children

\begin{tabular}{llll}
\hline & Controls $(n=18)$ & Dyslexics $(n=18)$ & $p$ value $t$ test \\
\hline Age (years) & & & \\
& $9.66(1.61)$ & $9.61(1.75)$ & \\
$8(n)$ & 4 & 4 & \\
$9(n)$ & 6 & 6 & \\
$10(n)$ & 2 & 2 & \\
$11(n)$ & 4 & 4 & \\
$12(n)$ & 2 & 2 & $<0.802$ \\
Words & & & \\
Accuracy & $38.9(1.05)$ & $34.75(3.83)$ & $<0.001$ \\
Speed (s) & $29.47(8.05)$ & & $<0.001$ \\
Pseudowords & & $28.50(4.93)$ & $<0.001$ \\
Accuracy & $35.5(2.59)$ & $95.31(22.13)$ & \\
Speed (s) & $53.76(16.52)$ & & \\
\hline
\end{tabular}

$n$ number, $s$ seconds 
General assessments The Praat software was used to extract various parameters from the .wav files. We investigated some prosodic features as previous studies of prosody (Miller \& Schwanenflugel, 2006, 2008; Schwanenflugel et al., 2004): pauses, fundamental frequency (range, slope, pitch change in the last syllable of the sentence, pitch change from the last peak to the end), syllable duration and intensity. First, we analysed characteristics of reading with reference to the full text, and then, we considered the prosody of particular sentence types, namely declarative, interrogative and exclamatory sentences. Measurements of the duration $(\mathrm{ms})$ and intensity $(\mathrm{dB})$ of the syllables before a pause (period pause) were based on two sentences of each type.

\section{Declarative sentences:}

- 'El jardín era grande y hermoso' [The garden was large and beautiful];

- 'El gigante estaba solo y malhumorado' [The giant was alone and angry];

Interrogative sentences:

- ¿¿Qué estás haciendo aquí?’ [What are you doing here?];

- ¿¿Qué está pasando en mi jardín?’ [What is happening in my garden?];

\section{Exclamatory sentences:}

- ‘QQué feliz soy aquí!' [How happy I am to be here!];

- ‘Qué egoísta he sido!’ [How selfish I have been!]).

Measurements of the remaining parameters were based on the first of the above sentences of each type. There were two reasons for considering only one sentence: first, the length and syntactic structure differences between sentences and, second, the number of mistakes made by readers on the second sentence. Unlike most studies of prosody, this study investigated exclamatory sentences, because they have a different prosodic contour from interrogative and declarative sentences.

We analysed the presence and duration of pauses across the full text. The following variables were scored:

- Total reading time (s): time taken to read the full text;

- Total speaking time (s): time taken to read the full text, excluding pauses;

- Mean duration of utterances (s): mean time between pauses;

- Number of comma pauses: number of pauses made at commas;

- Number of period pauses: number of pauses made at periods;

- Number of inappropriate pauses: number of pauses that did not coincide with a comma or periods;

- Total comma pausing time (s): total duration of pauses made at commas;

- Total period pausing time (s): total duration of pauses made at periods;

- Total inappropriate pausing time (s): total duration of pauses that did not coincide with a comma or full stop;

- Total pausing time (s): combined duration of all pauses;

- Mean comma pause duration (s): mean duration of pauses made at commas; 
- $\quad$ Mean period pause duration (s): mean duration of pauses made at periods;

- Mean inappropriate pause duration (s): mean duration of inappropriate pauses;

- Mean duration of pauses (s): mean duration of all the pauses.

From the sentences, different parameters were analysed, taking into account sentence type and knowledge reported in the literature.

Fundamental frequency $\left(F_{0}\right)$ measures $(\mathrm{Hz})$ :

Range (Hz). Distance between minimum fundamental frequency at the beginning of the sentence and the first peak in fundamental frequency.

Slope $(\mathrm{Hz} / \mathrm{s})$. Reduction in fundamental frequency from the first peak to the end of the sentence by time (a reduction in $F_{0}$ across a phrase is normal, Vaissière, 1983).

Pitch change at the beginning of the sentence. Two features were calculated: (i) rise in $F_{0}$ (Hz) from the beginning of the sentence to the first peak and (ii) rise in $F_{0}(\mathrm{~Hz})$ from the first to the second syllable

Pitch change at the end of the sentence. Two measures were calculated: (i) decrease in $F_{0}$ $(\mathrm{Hz})$, from the final peak to the end of the sentence, and (ii) decrease in $F_{0}(\mathrm{~Hz})$ during the last syllable, i.e. $F_{0}$ penultimate syllable $-F_{0}$ final syllable.

Duration measure:

Final syllable lengthening (ms): a comparison of the duration of pre-pause syllables with the mean duration of other syllables in the sentence. Studies of prosody suggest that the syllable preceding a pause is usually considerably longer than the other syllables in a sentence (Dowhower, 1991).

Intensity measure:

Intensity change at sentence end $(\mathrm{dB})$. The intensity of the last syllable was measured and compared to the mean intensity of the other syllables in the sentence. The intensity of syllable preceding the pause is usually lower than that of the other syllables (Vaissière, 1983).

These data were obtained by manually creating a TextGrid representing the different interval tiers (a tier is a connected sequence of bounded, labelled intervals): pauses, $F_{0}$, syllables, etc. and then using the relevant Praat scripts to collect the data. An example of TextGrid is shown in Fig. 1.

\section{Results}

Full-text analyses Variables related to the reading of the full text were analysed using SPSS.19 software. Group differences were assessed using independent samples $t$ tests. Group differences were found in all the parameters, except for the number of inter-clause pauses: pauses at commas and periods (see Table 2).

Children with dyslexia spent $69.41 \%$ of their time speaking and $30.59 \%$ pausing; whereas controls spent $79.28 \%$ of their time speaking and $20.72 \%$ pausing. 


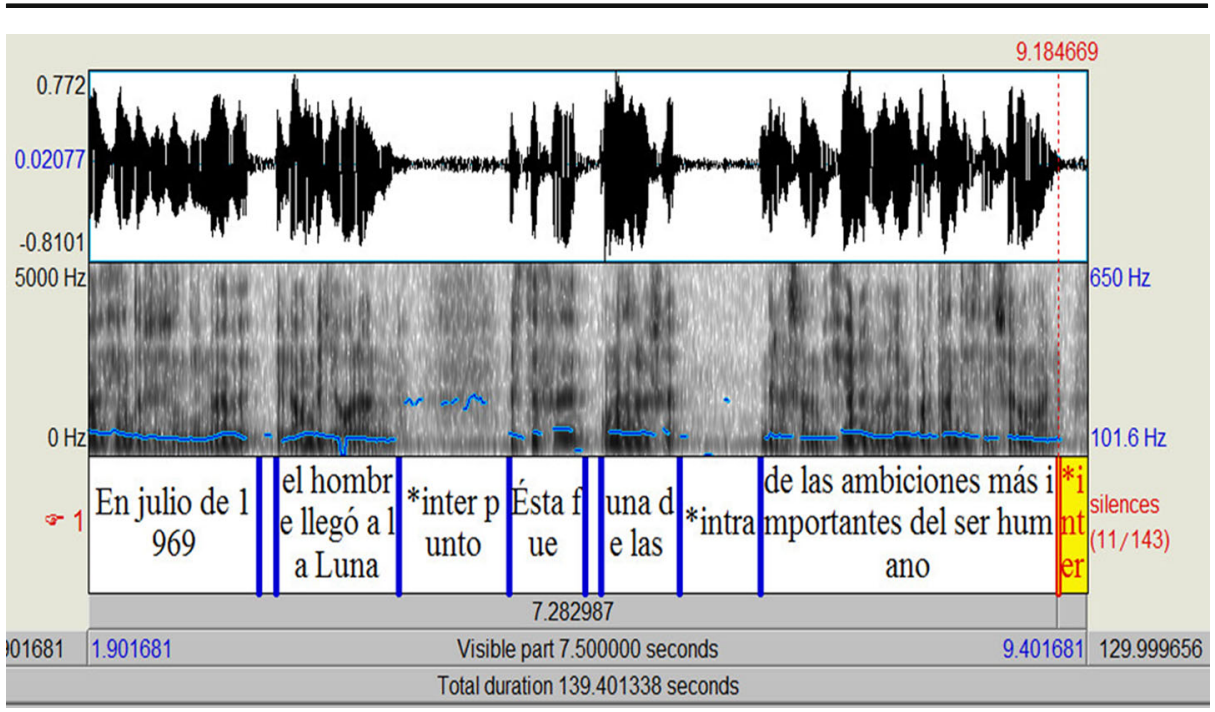

Fig. 1 Example of TextGrid with an interval tier, where pauses and utterances are labelled

Sentences analyses Sentences which were inaudible on the audio recording or contained reading mistakes (progression towards correct production of the whole word by sounding-out parts of the word, word substitutions, word omissions or insertions, non-word production) were treated as missing for these analyses (around $2 \%$ ). After confirming the normality of the data using Kolmogorov-Smirnov and Shapiro-Wilk tests, they were subjected to ANOVA using SPSS.

Declarative sentences There was a group effect in slope $\left(F_{(1,34)}=8.32, p=0.007\right.$, partial $\eta^{2}=0.19$ ), as the control group showed a greater decrease in $F_{0}$ between the first peak and the

Table 2 Text reading scores of the participants (dyslexic and control children)

\begin{tabular}{lllll}
\hline Parameter & Controls $(n=18)$ & Dyslexics $(n=18)$ & $p$ value & Ratio \\
\hline Total reading time (s) & $124.76(11.13)$ & $192.30(25.12)$ & $<0.001$ & 1.54 \\
Total speaking time (s) & $98.91(13.69)$ & $133.47(25.55)$ & $<0.001$ & 1.35 \\
Mean duration of utterances (s) & $1.78(0.37)$ & $1.36(0.26)$ & $<0.001$ & 0.76 \\
No. comma pauses & $5.10(2.12)$ & $6.11(2.02)$ & $=0.137$ & 1.20 \\
No. period pauses & $27.22(1.77)$ & $27.80(1.50)$ & $=0.317$ & 1.02 \\
No. inappropriate pauses & $25.06(15.36)$ & $68.22(35.05)$ & $<0.001$ & 2.72 \\
Total comma time (s) & $1.67(0.81)$ & $3.48(1.68)$ & $<0.001$ & 2.08 \\
Total period time (s) & $14.90(2.98)$ & $21.36(7.63)$ & $<0.001$ & 1.4 \\
Total inappropriate time (s) & $9.27(5.92)$ & $33.97(17.82)$ & $<0.001$ & 3.66 \\
Total pause duration (s) & $25.85(8.57)$ & $58.82(24.69)$ & $<0.001$ & 2.27 \\
Mean comma pause (s) & $0.34(0.09)$ & $0.55(0.15)$ & $<0.001$ & 1.61 \\
Mean period pause (s) & $0.54(0.09)$ & $0.76(0.25)$ & $<0.001$ & 1.40 \\
Mean inappropriate pauses (s) & $0.34(0.09)$ & $0.49(0.10)$ & $<0.001$ & 1.44 \\
Mean duration pauses (s) & $0.41(0.07)$ & $0.60(0.14)$ & $<0.001$ & 1.46 \\
\hline
\end{tabular}

$s$ seconds, No. number 
end of the sentence $\left(M_{\mathrm{d}}=55.68 \mathrm{~Hz}, \mathrm{SD}=22.99 ; M_{\mathrm{c}}=91.27 \mathrm{~Hz}, \mathrm{SD}=46.83\right)$. There were also group effects in pitch change at the beginning of the sentence, i.e. beginning to first peak $\left(F_{(1,}\right.$ 34) $=5.65, p=0.024$, partial $\left.\eta^{2}=0.15\right)$, the rise in pitch was greater in the control group than the dyslexic group $\left(M_{\mathrm{d}}=45.11 \mathrm{~Hz}, \mathrm{SD}=33.11 ; M_{\mathrm{c}}=73.06 \mathrm{~Hz}, \mathrm{SD}=35.36\right)$; in pitch change during the last syllable $\left(F_{(1,34)}=5.76, p=0.022\right.$, partial $\left.\eta^{2}=0.15\right)$, with a greater pitch decrease in the control than in the dyslexic group $\left(M_{\mathrm{d}}=12.87 \mathrm{~Hz}, \mathrm{SD}=9.69 ; M_{\mathrm{c}}=23.31 \mathrm{~Hz}\right.$, $\mathrm{SD}=15.09)$, and pitch decrease from the final peak $\left(F_{(1,34)}=6.20, p=0.018\right.$, partial $\left.\eta^{2}=0.16\right)$, with a bigger pitch decrease in the control group than the dyslexic group $\left(M_{\mathrm{d}}=74.69 \mathrm{~Hz}, \mathrm{SD}=30.82 ; M_{\mathrm{c}}=109.78 \mathrm{~Hz}, \mathrm{SD}=49.25\right)$.

There was a group effect on syllable duration $\left(F_{(1,34)}=5.95, p=0.020\right.$; partial $\left.\eta^{2}=0.15\right)$, as dyslexics took longer to read syllables than controls $\left(M_{\mathrm{d}}=0.247 \mathrm{~ms}, \mathrm{SD}=0.049\right.$; $\left.M_{\mathrm{c}}=0.213 \mathrm{~ms}, \mathrm{SD}=0.029\right)$. There was also a syllable effect $\left(F_{(1,34)}=79.53, p<0.001\right.$; partial $\left.\eta^{2}=0.71\right)$, such that internal syllables were shorter than final syllables $\left(M_{\mathrm{i}}=0.20 \mathrm{~ms}\right.$, $\left.\mathrm{SD}=0.04 ; M_{\mathrm{f}}=0.26 \mathrm{~ms}, \mathrm{SD}=0.05\right)$. The magnitude of the difference between syllable types was greater for controls than for dyslexics, but the group $\times$ syllable interaction was not significant (dyslexics: $M_{\mathrm{i}}=0.22 \mathrm{~ms}, \mathrm{SD}=0.04 ; M_{\mathrm{f}}=0.27 \mathrm{~ms}, \mathrm{SD}=0.06$; controls: $\left.M_{\mathrm{i}}=0.18 \mathrm{~ms}, \mathrm{SD}=0.03 ; M_{\mathrm{f}}=0.25 \mathrm{~ms}, \mathrm{SD}=0.04\right)$. There were no group effects on range $(p=.295), F_{0}$ rise between the first and second syllables $(p=0.191)$ or intensity change at the sentence end $(p=0.540)$.

Interrogative sentences The only fundamental frequency variable to show a group effect was range $\left(F_{(1,34)}=16.42, p<0.001\right.$, partial $\left.\eta^{2}=0.33\right)$, where dyslexic children showed a large change in $F_{0}$ at the beginning of interrogative sentences $\left(M_{\mathrm{d}}=141.61 \mathrm{~Hz}, \mathrm{SD}=90.10\right.$; $\left.M_{\mathrm{c}}=54.36 \mathrm{~Hz}, \mathrm{SD}=15.07\right)$.

There was a syllable effect $\left(F_{(1,34)}=212.44, p<0.001\right.$, partial $\left.\eta^{2}=0.86\right)$ such that final syllables were longer than internal syllables $\left(M_{\mathrm{i}}=0.17 \mathrm{~ms}, \mathrm{SD}=0.04 ; M_{\mathrm{f}}=0.33 \mathrm{~ms}\right.$, $\mathrm{SD}=0.07$ ), but no group $\times$ syllable interaction was found (dyslexics: $M_{\mathrm{i}}=0.18 \mathrm{~ms}$, $\mathrm{SD}=0.04 ; M_{\mathrm{f}}=0.33 \mathrm{~ms}, \mathrm{SD}=0.08$; controls: $M_{\mathrm{i}}=0.16 \mathrm{~ms}, \mathrm{SD}=0.04 ; M_{\mathrm{f}}=0.34 \mathrm{~ms}$, $\mathrm{SD}=0.05)$. There were no group differences in slope $(p=0.438)$, pitch rise from beginning to first peak $(p=0.894)$, pitch rise from first to second syllable $(p=0.502)$, pitch decrease from final peak $(p=0.557)$, pitch decrease in last syllable $(p=0.851)$ or intensity change at sentence end $(p=0.368)$.

Exclamatory sentences There was a group effect on pitch change between first and second syllables $\left(F_{(1,34)}=4.15, p=0.050\right.$; partial $\left.\eta^{2}=0.12\right)$, the dyslexic group showed a rise in pitch whereas the control group showed a fall in pitch $\left(M_{\mathrm{d}}=7.72 \mathrm{~Hz}, \mathrm{SD}=15.35 ; M_{\mathrm{c}}=-12.90 \mathrm{~Hz}\right.$; $\mathrm{SD}=37.64$ ). The pitch change from sentence beginning to first peak was not calculated, because in the control group, the first peak coincided with the second syllable.

The slope in pitch was steeper in the control group than in the dyslexic group $\left(M_{\mathrm{d}}=120.44 \mathrm{~Hz}, \mathrm{SD}=52.99 ; M_{\mathrm{c}}=160.34 \mathrm{~Hz}, \mathrm{SD}=81.17\right)$, but the difference was not significant $(p=0.09)$. There was a group effect on syllable duration $\left(F_{(1,34)}=4.53, p=0.04\right.$; partial $\left.\eta^{2}=0.12\right)$, and the dyslexic group took longer to read a syllable than the control group $\left(M_{\mathrm{d}}=0.26 \mathrm{~ms}, \mathrm{SD}=0.04 ; M_{\mathrm{c}}=0.23 \mathrm{~ms} ; \mathrm{SD}=0.03\right)$. There was also a syllable effect $\left(F_{(1,}\right.$ 34) $=46.26, p<0.001$; partial $\left.\eta^{2}=0.58\right)$, such that internal syllables were shorter than final syllables $\left(M_{\mathrm{i}}=0.21 \mathrm{~ms}, \mathrm{SD}=0.04 ; M_{\mathrm{f}}=0.28 \mathrm{~ms}, \mathrm{SD}=0.06\right)$. As in the declarative sentences, the magnitude of the difference between syllable types was greater in the control group, but there was no group $\times$ syllable interaction (dyslexics: $M_{\mathrm{i}}=0.23 \mathrm{~ms}, \mathrm{SD}=0.03 ; M_{\mathrm{f}}=0.28 \mathrm{~ms}$, 
$\mathrm{SD}=0.08$; controls: $\left.M_{\mathrm{i}}=0.19 \mathrm{~ms}, \mathrm{SD}=0.04 ; M_{\mathrm{f}}=0.27 \mathrm{~ms}, \mathrm{SD}=0.04\right)$. In addition, there were no group differences in range $(p=0.190)$, pitch decrease from final peak $(p=0.989)$, pitch rise during the last syllable $(p=0.427)$ and intensity change at sentence end $(p=0.724)$.

Figure $2 \mathrm{a}-\mathrm{f}$ shows a melodic contour example of each sentence type for both groups.

Correlation analyses After the ANOVAs, we performed correlations between prosodic parameters (those in which significant differences between groups were found) and reading measures (accuracy and speed), in order to gain insight into the association between reading skills and reading prosody, as suggested by other studies (Binder et al., 2013; Schwanenflugel et al., 2004) (see Table 3).

As observed, there is a relationship between use of prosodic features and reading ability. Specifically, we observed that in declarative sentences, reading speed was associated with the slope of fundamental frequency (the longer time in reading, the smaller was the slope); reading speed and accuracy were associated with pitch rise at the beginning of the sentence, and

a

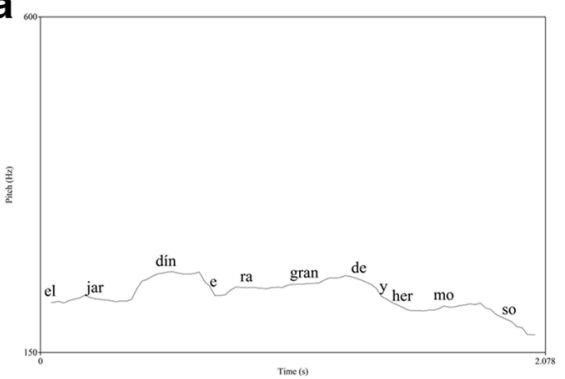

b

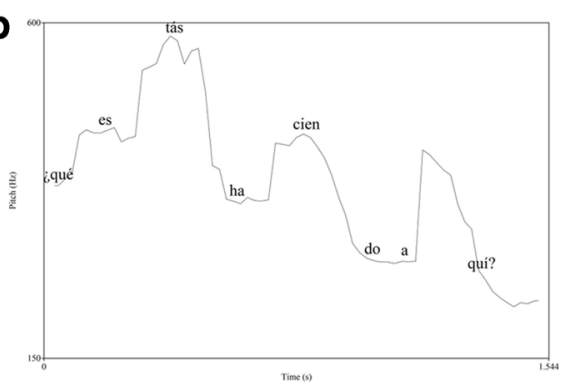

C

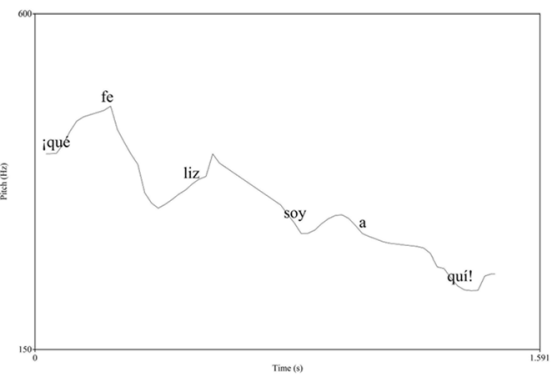

d

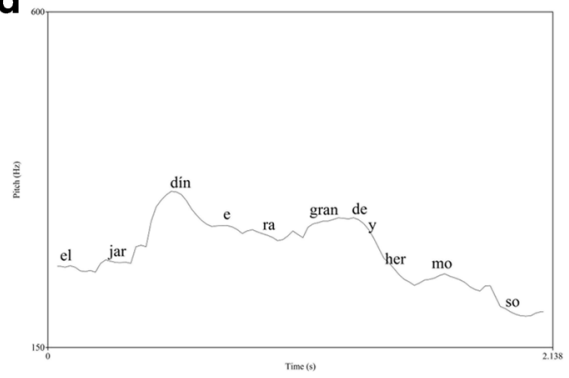

e

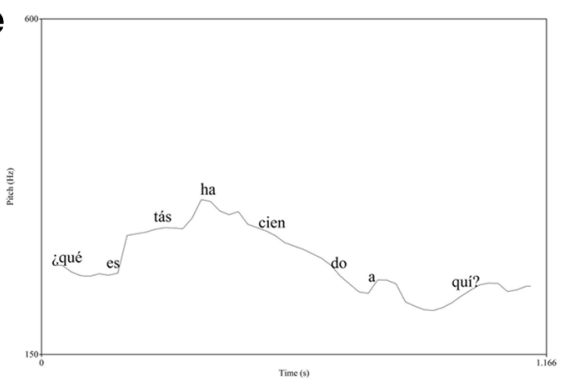

f

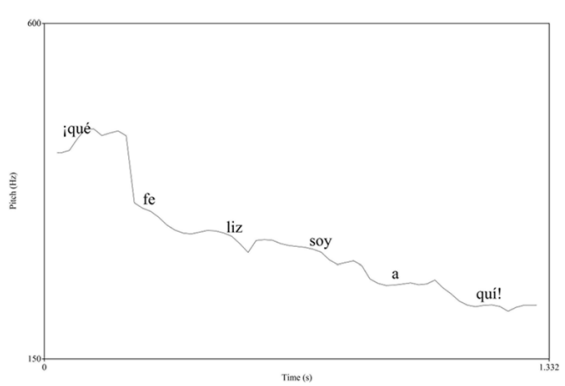

Fig. 2 Examples of melodic contour by dyslexic children: declarative (a), interrogative (b) and exclamatory (c) sentences. Examples of melodic contour by control children: declarative (d), interrogative (e) and exclamatory (f) sentences 
Table 3 Correlations between prosodic measures and reading measures in every sentence type (for children)

\begin{tabular}{lllll}
\hline & Words accuracy & Words speed & Pseudowords accuracy & Pseudowords speed \\
\hline Declarative sentences & & & & \\
$\quad$ Slope & 0.208 & $-0.355^{*}$ & 0.172 & $-0.488^{* *}$ \\
$\quad$ Pitch rise & $0.300^{*}$ & $-0.410^{* *}$ & $0.459^{* *}$ & $-0.456^{* *}$ \\
$\quad$ Pitch last syllable & $0.308^{*}$ & -0.153 & 0.201 & -0.212 \\
$\quad$ Pitch declination & 0.138 & -0.191 & 0.222 & -0.280 \\
Exclamatory sentences & & & & 0.150 \\
$\quad$ Pitch at the beginning & -0.139 & 0.208 & $-0.326^{*}$ & \\
Interrogative sentences & & & $-0.610^{* *}$ & $0.500^{* *}$ \\
$\quad$ Range & $-0.581^{* *}$ & $0.501^{* *}$ & & \\
\hline
\end{tabular}

*Significant at 0.05 level (one tailed), **significant at 0.01 level (one tailed)

reading accuracy (word recognition) was related to the pitch rise of the last syllable (greater reading accuracy was associated with higher pitch). In exclamatory sentences, decoding (pseudoword accuracy) was related to pitch at the beginning of sentences (the best readers used a lower pitch). Finally, in interrogative sentences, both reading accuracy and reading speed (decoding and word recognition) were correlated with range of fundamental frequency. These results suggest that prosodic parameters may be determined by the accuracy and speed of reading.

\section{Discussion}

We found that the reading prosody of dyslexic children differed from that of typical readers. As predicted, dyslexic children took longer to read a text than controls and the proportion of reading time spent in pauses was also different; dyslexic children spent more time pausing than typical readers. It should also be highlighted that dyslexic children made more inappropriate pauses than control children, breaking up words and sentences, so their reading sounded hesitant and lacking in expression.

In addition, when reading declarative sentences, dyslexics produced a smaller rise in pitch at the beginning of the sentence than controls, as well as a smaller slope of fundamental frequency, a smaller pitch decrease during the last syllable and a smaller pitch decrease from the last peak to the end of the sentence. There was also a difference in how the beginning of exclamatory sentences (where an orthographic mark is included at the beginning in Spanish) was treated; dyslexic children's pitch rose between the first and second syllables, a feature not shown by the control group. Finally, when reading interrogative sentences, dyslexic participants had a larger fundamental frequency range at the beginning of wh-questions which was due to an increase in $F_{0}$. These differences in prosody were related to reading ability: children who scored more highly on measures of reading ability seemed to read more expressively.

These results suggest that reading prosody is related to reading competence and that dyslexic children use prosody differently from typical readers, but we were also interested in how the reading of dyslexic children changes as they get older. Does their reading fluency improve? What is the prosodic profile of dyslexic adults? Some studies have reported that 
dyslexia persists in adulthood regardless of education level and reading experience (Bruck, 1990; Snowling, Muter, \& Carroll, 2007; Suárez-Coalla \& Cuetos, 2015; Undheim, 2009). It may be concluded from the available evidence that reading speed continues to be a problem for adults with dyslexia (Bruck, 1990, 1992; Hatcher, Snowling, \& Griffiths, 2002; NergårdNilssen \& Hulme, 2014; Parrila, Georgiou, \& Corkett, 2007; Shaywitz et al., 1999; see Swanson \& Hsieh, 2009 for a review); however, nothing is known about the use of suprasegmental features during reading; it is also not known whether experience helps dyslexic adults to read more expressively. We carried out a second reading experiment with dyslexic adults to address these questions.

There is further discussion of the results of experiment 1 , including how they related to previous research in the "General discussion" section.

\section{Experiment 2}

\section{Participants}

Twenty-three adults with dyslexia (eight men; $M_{\mathrm{age}}=34.16, \mathrm{SD}=11.97$ ) and 23 controls (eight men; $M_{\text {age }}=34.74, \mathrm{SD}=11.72$ ) matched in terms of age, gender, socio-economic status (middle class) and education level (post-secondary education or a university degree) were enrolled in this study. None of the participants had a history of brain injury or neurological problems, and all were native speakers of Spanish, with normal hearing and normal or corrected-to-normal vision. There were no group differences in age or years of education. All participants in this study (both dyslexics and controls) had already participated in a previous study of dyslexia in adulthood, conducted in the Department of Psychology, University of Oviedo (Afonso, Suárez-Coalla, \& Cuetos, 2015; Suárez-Coalla \& Cuetos, 2015). A detailed questionnaire was administered to potential dyslexic participants to obtain demographic information, a history of reading and writing difficulties during childhood and adulthood, family history of reading and writing difficulties and a history of language therapy and other assistance with language problems (see Giménez, Luque, López-Zamora, \& Fernández-Navas, 2015; Leinonen, Müller, Leppänen, Aro, Ahonen, \& Lyytinen, 2001). All dyslexic participants reported persistent difficulties in completing exams, spelling mistakes, difficulty finishing homework and receipt of extra homework intended to improve reading and writing performance. After administration of the questionnaire, the diagnosis of dyslexia was confirmed by administering a test of general ability (Wechsler, 1981) and a test of reading processes (Ramos \& Cuetos, 2005). The reading battery included tasks designed to evaluate lexical, syntactic and semantic processing. The reading performance in the lexical and sublexical subtests was considered to confirm a reading deficit. Although there are no formal criteria for dyslexia in Spanish-speaking adults, we found that the reading performance (speed and accuracy when reading words and pseudowords) of our dyslexic group was 1.5 to $2 \mathrm{SD}$ below the mean of the control group (see Table 4).

\section{Materials and methods}

Material As in the previous experiment, the task consisted of a reading a text aloud. The text was 228 words long and was entitled 'Viaje a la luna [Trip to the Moon]'; it was based on a text about the first trip to the moon (included in Jiménez \& Alonso, 2005) (see Appendix). It 
Table 4 Means and standard deviations for demographic characteristics and reading scores of control and dyslexic adults

\begin{tabular}{llll}
\hline & Controls $(n=23)$ & Dyslexics $(n=23)$ & $p$ value $t$ test \\
\hline Age & $34.74(11.72)$ & $34.16(11.97)$ & $=0.636$ \\
Education (years) & $15.36(2.24)$ & $15.10(2.02)$ & $=0.981$ \\
Words & & & $<0.001$ \\
$\quad$ Accuracy (out of 40) & $39.9(0.31)$ & $38.7(1.30)$ & $<0.001$ \\
$\quad$ Speed (s) & $23.75(6.21)$ & $36.35(10.25)$ & $<0.001$ \\
Pseudowords & & & $<0.001$ \\
$\quad$ Accuracy (out of 40) & $38.7(2.11)$ & $34.77(2.91)$ & \\
Speed (s) & $35.75(6.68)$ & $63.05(13.74)$ & \\
\hline
\end{tabular}

$s$ seconds

was a narrative text with declarative, exclamatory and interrogative sentences. The readability indices for the text were as follows: Flesh-Kincaid Grade Level $=10.42$, Flesh Reading Ease Score $=45.44$, Flesh-Szigriszt score $=74.46$ and Flesh Fernández-Huerta score $=78.82$. The text was presented on a paper in double-spaced, 12-point Times New Roman font. Participant read it aloud without having had the opportunity to read silently, individually in a quiet room. The readings were recorded using a SONY ICD-UX533 recorder, and Praat software (Boersma \& Weenink, 2011) was used to process the .wav files as described for experiment 1.

General assessments As in experiment 1, some parameters were collected from the full text and others from specific sentences. The sentences are listed below.

Declaratives sentences:

'La experiencia de visitar la luna es indescriptible' [The experience of visiting the moon is indescribable]

'Me fascinaba verla brillar a lo lejos' [I was fascinated to see it shining in the distance]

Exclamatory sentences:

‘QQué bonita es la luna!' [How beautiful the moon is!]

‘Qué suerte poder vivir en un sitio tan maravilloso!' [How lucky we are to live in such a wonderful place!])

Interrogatives sentences:

‘Podré regresar de nuevo a la Tierra?' [Will I be able to return to Earth?]

‘'Tendrá habitantes como la tierra?’ [Will it have people like those on Earth?])

The variables based on reading of the full text were the same as in experiment 1 . To study duration $(\mathrm{ms})$ and intensity $(\mathrm{dB})$ of the syllables, the two sentences of each type were considered. Measurements of the remaining parameters were based on the first of the above sentence of each type.

The variables for declarative and exclamatory sentences were also the same as in experiment 1 , but for interrogative sentences, we also collected data on the pitch rise at the end of the 
sentence (difference between pitches of the two last syllables; change in pitch between last trough and sentence end) because the interrogative sentence was a yes-no question and this is reported to be a frequent feature of Spanish prosody in such cases.

Participants were assessed individually at the Basic Psychology Laboratory of the University of Oviedo, Spain. Participants were fully informed about the task that they would be asked to perform and gave written consent to participation.

\section{Results}

Full-text analyses Independent samples $t$ tests were used for group comparisons. There were group differences in different parameters investigated: time taken to read the full text (including speaking and pausing time), time in inappropriate pauses (time and number) and number of pauses in periods (see Table 5).

It should also be highlighted that adults with dyslexia spent $78.42 \%$ of their reading time speaking and $21.58 \%$ pausing, whereas controls spent $81.03 \%$ of their reading time speaking and $17.97 \%$ pausing.

Sentences analyses ANOVAs on sentence variables were carried out using SPSS.19 software, after confirming that the data were normally distributed.

Declarative sentences There was a group difference in the pitch decrease from the last peak to the sentence end $\left(F_{(1,40)}=4.93, p=0.032\right.$, partial $\left.\eta^{2}=0.11\right)$, where the decrease was greater in the control group $\left(M_{\mathrm{d}}=38.76 \mathrm{~Hz}, \mathrm{SD}=50.86 ; M_{\mathrm{c}}=76.85 \mathrm{~Hz}, \mathrm{SD}=57.62\right)$. There were no group differences in the other parameters: range $(p=0.911)$, slope $(p=0.935)$, pitch rise between first and second syllables $(p=0.930)$, pitch rise from beginning to first peak

Table 5 Text reading scores of the participants (dyslexic and control adults)

\begin{tabular}{lllll}
\hline Parameter & Controls $(n=23)$ & Dyslexics $(n=23)$ & $p$ value $t$ test & Ratio \\
\hline Total reading time (s) & $95.88(12.87)$ & $119.74(21.84)$ & $<0.001$ & 1.24 \\
Total speaking time (s) & $78.65(9.16)$ & $93.91(13.87)$ & $<0.001$ & 1.19 \\
Mean duration of utterances (s) & $2.11(0.34)$ & $1.87(0.36)$ & $=0.028$ & 0.88 \\
No. comma pauses & $6.91(2.73)$ & $7.87(2.47)$ & $=0.220$ & 1.13 \\
No. period pauses & $22.17(0.71)$ & $22.87(0.45)$ & $<0.001$ & 1.03 \\
No. inappropriate pauses & $6.74(4.5)$ & $21.17(16.66)$ & $<0.001$ & 3.14 \\
Total comma time (s) & $2.44(1.11)$ & $3.37(1.78)$ & $=0.040$ & 1.38 \\
Total period time (s) & $12.39(3.06)$ & $15.32(3.99)$ & $=0.008$ & 1.23 \\
Total inappropriate time (s) & $2.39(1.80)$ & $7.13(17.82)$ & $<0.001$ & 3.66 \\
Total pause time (s) & $25.85(8.57)$ & $58.82(6.45)$ & $<0.001$ & 2.98 \\
Mean comma pause (s) & $0.35(0.06)$ & $0.45(0.16)$ & $=0.153$ & 1.28 \\
Mean period pause (s) & $0.55(0.13)$ & $0.67(0.17)$ & $=0.016$ & 1.22 \\
Mean inappropriate pauses (s) & $0.31(0.11)$ & $0.33(0.11)$ & $=0.467$ & 1.06 \\
Mean duration pauses (s) & $0.41(0.08)$ & $0.48(0.11)$ & $=0.060$ & 1.17 \\
\hline
\end{tabular}

$s$ seconds, No. number 
$(p=0.130)$, pitch decrease during the last syllable $(p=0.366)$, final syllable lengthening $(p=0.124)$ and intensity change at sentence end $(p=0.181)$.

Interrogative sentences There was a group difference in pitch rise at sentence end (comparison of last two syllables) $\left(F_{(1,44)}=4.15, p=0.048\right.$, partial $\left.\eta^{2}=0.09\right)$, as dyslexic adults showed a smaller pitch rise than controls $\left(M_{\mathrm{d}}=8.83 \mathrm{~Hz}, \mathrm{SD}=42.103 ; M_{\mathrm{c}}=28.73 \mathrm{~Hz}\right.$, $\mathrm{SD}=20.53)$. There were no group differences in the other parameters: range $(p=0.227)$, slope $(p=0.238)$, pitch rise between first and second syllables $(p=0.733)$, pitch rise from beginning to first peak $(p=0.133)$, final syllable lengthening $(p=0.129)$ and intensity change at sentence end $(p=0.164)$.

Exclamatory sentences There were no group differences in the investigated prosodic features in this sentence type: range $(p=0.799)$, slope $(p=0.352)$, pitch rise at the beginning of the sentence (first peak coincides with the second syllable, so only one indicator of this parameter with this sentence type) $(p=0.246)$, pitch decrease between last peak and sentence end $(p=0.878)$, pitch decrease during the last syllable $(p=0.462)$, final syllable lengthening $(p=0.137)$ and intensity change at sentence end $(p=0.859)$.

Figure $3 \mathrm{a}-\mathrm{f}$ shows examples of the melodic contour for all sentence types.

Correlation analyses We analysed correlations between the prosodic parameters (those in which significant differences between groups were found) and the reading parameters (accuracy and speed). As observed (see Table 6), some significant correlation was found, since accuracy and speed appear to be related to prosodic features. Specifically, in declarative sentences, there was an association between reading speed and the pitch decrease at the sentence end; the pitch decrease was smaller in slower readers. This seems to suggest that this pitch decrease may be determined by reading speed. In interrogative sentences, the pitch rise at the end of the sentence was associated with both reading accuracy and decoding speed, suggesting that this pitch change feature is influenced by reading ability. The relationship between reading ability and prosody was less obvious in dyslexic adults than children, but it could be normal because the reading problems are stronger in children than adults with dyslexia.

\section{Discussion}

The analyses of the reading aloud of dyslexic adults revealed that they took longer to read the text and paused more often than the controls. These results confirm that people with dyslexia continue to have problems with reading speed, even when they are experienced readers.

There were some differences between the reading prosody of people with dyslexia and typical readers in adulthood, but not as many as in childhood. The pitch decrease at the end of declarative sentences was greater in the adult control group than in the adult dyslexic group, and dyslexic adults also showed a smaller pitch rise at the end of interrogative sentences than controls. Comparing the results of this experiment with those from the experiment with children suggests that dyslexic adults' main problem with reading is lack of speed; unlike children with dyslexia, they appear to be able to read with normal expression and most of their prosodic differences relate to end of sentence features. 
a

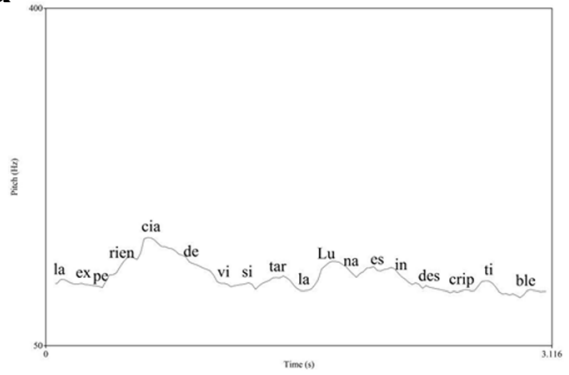

b

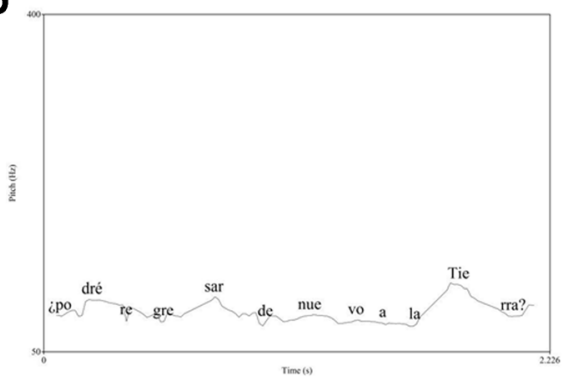

C

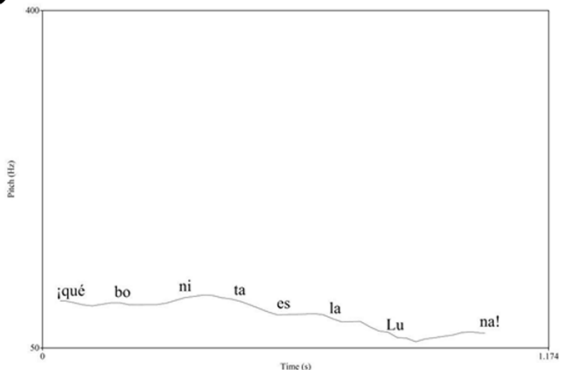

d

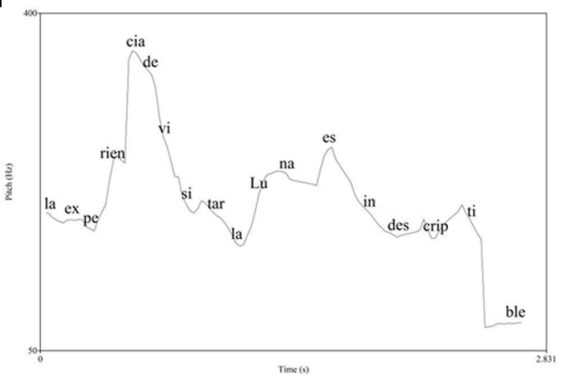

e

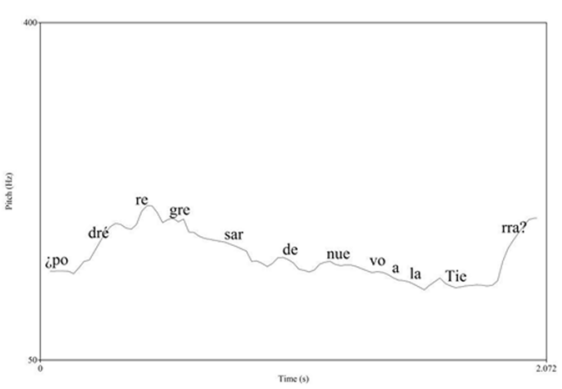

f

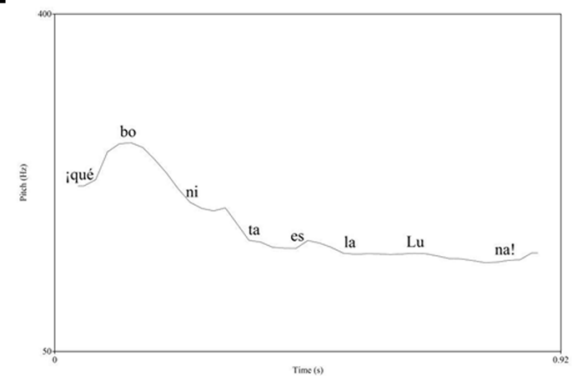

Fig. 3 Examples of melodic contour by dyslexic adults: declarative (a), interrogative (b) and exclamatory (c) sentences. Examples of melodic contour by control adults: declarative (d), interrogative (e) and exclamatory (f) sentences

As with experiment 1, a more detailed discussion of these results is provided below, in the "General discussion" section.

\section{General discussion}

The purpose of this study was to compare the reading prosody of dyslexic and typical Spanishspeaking readers, as it had been reported that English-speaking people with poor reading skills show abnormal reading prosody (Binder et al., 2013, Schwanenflugel et al., 2004). We analysed several supra-segmental parameters based on spectrographic data obtained from recordings of reading aloud. Specifically, we investigated pausing and reading rate (number of pauses, duration of pauses and utterances), pitch changes, intensity changes and syllable duration. Data from children with and without dyslexia were analysed in the first experiment, 
Table 6 Correlations between prosodic measures and reading measures in every sentence type (for adults)

\begin{tabular}{lllll}
\hline & Words accuracy & Words speed & Pseudowords accuracy & Pseudowords speed \\
\hline $\begin{array}{c}\text { Declarative sentences } \\
\text { Pitch declination }\end{array}$ & 0.153 & $-0.272^{*}$ & 0.210 & $-0.271^{*}$ \\
$\begin{array}{c}\text { Interrogative sentences } \\
\text { Pitch rise at the end }\end{array}$ & $0.300^{*}$ & -0.167 & $0.366^{* *}$ & $-0.290^{* *}$ \\
\hline
\end{tabular}

*Significant at 0.05 level (one tailed), **significant at 0.01 level (one tailed)

and in the second experiment, we investigated the performance of adults with dyslexia using a similar task.

Children with dyslexia took longer to read a narrative text than matched controls; they also spent more time pausing and made more inappropriate pauses than typical readers, findings which are consistent with other studies (e.g. Binder et al., 2013). There were also differences between the groups with respect to fundamental frequency. In declarative sentences, children with dyslexia showed a lower slope in fundamental frequency, a smaller pitch rise at the beginning of sentences and a smaller pitch decrease at the end of the sentence. In exclamatory sentences, control and dyslexic children showed opposite patterns in pitch at the beginning of the sentences; in dyslexic children, there was a rise in pitch between the first and second syllables, whilst in controls, there was decrease in pitch over the same period. Finally, in interrogative sentences, dyslexic children but not controls showed a large rise in pitch and the beginning of the sentence.

The results on pausing are consistent with those of other studies, where children with poor reading skills (Miller \& Schwanenflugel, 2006, 2008; Schwanenflugel et al., 2004) and dyslexic children (Alves et al., 2015; De Luca et al., 2013) paused significantly longer than skilled readers. Children with dyslexia also made more inappropriate pauses, breaking-up phrases and words such that overall reading performance was hesitant and lacking in fluency. There was, however, no difference between the number of clause-ending pauses made by dyslexic and control children, indicating that dyslexics recognise these punctuation marks as signals to pause, although it takes them longer to resume reading. These findings confirm the existence of a relationship between decoding deficits and pausing; it has already been argued that children who read quickly and accurately use a relatively small number of short pauses compared with children with a decoding impairment (Alves et al., 2015; Benjamin \& Schwanenflugel, 2010; De Luca et al., 2013). It is known that dyslexic children have difficult learning and automating the alphabetic code and, consequently, with the development of orthographic representations of words (Ehri \& Saltmarsh, 1995; Manis, 1985; Reitsma, 1983). Longer and more frequent pausing and longer articulation times are therefore characteristics of the reading of dyslexic children (Davies, Rodríguez-Ferreiro, Suárez, \& Cuetos, 2013; De Luca et al., 2013). The longer and more frequent pauses seen in dyslexia have also been interpreted as a compensatory strategy which is used to ensure comprehension (compensatory-encoding model: Walczyk, Marsiglia, Johns, \& Bryan, 2004).

Regarding the use of prosodic features, we found substantial differences between the two groups of children; these results are in line with previous reports that expressiveness emerges as reading becomes automatic (Miller \& Schwanengflugel, 2006; Schwanengflugel et al., 2006). As children's reading speed and accuracy improve, they start to use adult-like prosody, 
but if they have problems decoding, they lack the cognitive resources to engage in pitch variation. In this study, we examined certain features of the prosody of several sentence types in dyslexia, extending previous research by Alves et al. (2015), which reported lower $F_{0}$ variation in Portuguese-speaking dyslexic children. It is interesting to note that dyslexic children showed greater rises in fundamental frequency than controls in exclamatory and interrogative sentences, but not in the declarative sentences. This suggests that dyslexic children perceive the orthographic marks at the start of interrogative and exclamatory sentences $(i, i)$ and respond with an excessive rise in pitch. In other cases, children with dyslexia showed limited variation in pitch and an attenuation of the typical variations in pitch during the course of sentences.

One might hypothesise that dyslexic children's reading problems impede their manipulation of fundamental frequency. Researchers have recognised that $F_{0}$ fluctuations are controlled linguistically, as $F_{0}$ is related to sentence type and duration (Ohala, 1978; Prieto, D'Imperio, Elordieta, Frota, \& Vigário, 2006; Tondering, 2011; Umeda, 1982); it is therefore necessary to anticipate some features of sentences (type, length, and structure) in order to read expressively. It is possible that because dyslexics use more resources for decoding and word recognition than their peers, they have difficulty anticipating some linguistic characteristics. The correlation analyses, which showed that some prosodic cues were related to reading accuracy and reading speed, seem to corroborate this hypothesis. It nevertheless appears that certain prosodic features, such as slope in fundamental frequency, are directly related to reading speed: the more slowly an individual reads, the smoother the slope will be.

In experiment 2, we confirmed that the deficit in reading speed which is associated with dyslexia persists into adulthood, even when they reading a text (De Luca et al., 2013; Szenkovits \& Ramus, 2005; Suárez-Coalla \& Cuetos, 2015; Tops, Callens, Lammertyn, Van Hees, \& Brysbaert, 2012). Adults took longer to read a narrative text aloud and also made more frequent and longer inappropriate pauses than controls, similar to the pattern found in dyslexic children. These findings suggest that the deficit in reading speed which is associated with dyslexia persists into adulthood, regardless of reading experience and education, and that the reading of adults with dyslexia remains more fragmented and hesitant than that of peers without dyslexia.

Adults with dyslexia differed from the control group with respect to changes in fundamental frequency at the end of declarative and interrogatives sentences; however, there were no differences in changes at the beginning of these sentence types and no differences in the prosody of exclamatory phrases. As stated above, fluctuations in $F_{0}$ at the end of sentences may depend on planning of articulation, which may be more challenging for people with dyslexia. Binder et al. (2013) found that adults with poor literacy showed the typical decrease in pitch at the end of declarative sentences but failed to vary their pitch in interrogative sentences. These authors argued that whilst declarative sentences are frequent and thus familiar (especially in written discourse), readers encounter fewer interrogative sentences when reading and so it is easier for readers to plan declarative prosody. It is possible that in this study, the absence of differences in exclamatory sentences might be due to the length of the sentences, because exclamatory sentences were only five words long, whereas the interrogative and declarative sentences were seven to eight words long. It would be interesting to compare sentences of different lengths to gain insight into phrase planning. Moreover, it is important to note that adults do not show a striking rise in pitch over the course of interrogative and exclamatory sentences, suggesting that they pay less attention to orthographic marks than children. Finally, as in the experiment with children, we found that a relationship was found between reading prosody and reading ability. The results of both experiments suggest that 
reading ability (decoding or access to phonological representations) being closely linked to use of prosodic features when reading a connected text.

In summary, this study provides information about reading prosody in people with dyslexia. To the authors' knowledge, it is the first study of reading prosody in Spanish people with dyslexia. The results confirmed that even experienced dyslexic readers show a deficit in reading speed. It was also found that people with dyslexia differ from skilled readers in their use of prosodic features, providing corroboration for the notion that prosody is related to fast, efficient reading and emerges as reading becomes more automatic. The main differences between typical readers and dyslexic readers seem to relate to performance of pitch changes, but the pattern of differences varied slightly between children and adults. Children with dyslexia differed from their peers with respect to prosodic features of the beginnings of sentences, and it is striking that they show exaggerated pitch contouring when faced with a prosodic mark $(i$ or $i)$. In contrast, the prosodic differences associated with dyslexia in adults appear to be concentrated at the end of sentences, probably because adults with dyslexia have difficulty anticipating structural features. The age-related differences in the pattern of prosodic abnormalities appear to be due to use of compensatory strategies by adults, who nevertheless continue to display abnormalities of expression when reading aloud. These results suggest that expressive reading depends on automation of decoding and word recognition and that the relationship between reading ability and prosody is apparent in regular orthographic systems.

In any case, it is necessary to continue deepening in this field and, clearly, more evidence is necessary to have powerful conclusions. It would also be interesting to investigate how prosody in typical and dyslexic readers is related to variables such as lexical frequency, sentence length and grammatical structure, to gain insight into the factors influencing prosody in people with dyslexia. It would also be interesting to compare reading prosody by dyslexic people and controls matched for reading ability, in order to determine whether the prosodic abnormalities found in people with dyslexia are a consequence of poor reading skills.

Acknowledgments This study was funded by Grant PSI2012-31913 from the Spanish Government and supported by a predoctoral Grant from the Foundation for the Promotion of Applied Scientific Research and Technology in Asturias (FICYT). The authors would like to thank Paloma Vegas Viña for their assistance in testing some participants.

\section{Appendix}

Spanish version of children's text:

\section{El gigante egoísta}

Un niño solía jugar en el jardín del Gigante. El jardín era grande y hermoso. En él había todo tipo de árboles: un abeto, un naranjo, una secuoya, una palmera, una magnolia,... También había algún pájaro que se posaba en los árboles y cantaba con dulzura.

- ¿Qué feliz soy aqui! - gritaba el niño.

Un día el Gigante llegó al castillo y cuando vio al niño dijo:

- ¿Qué estás haciendo aqui? ¡Fuera de mi jardín! 
El niño escapó corriendo y el gigante cerró la puerta del jardín del castillo.

Cuando llegó la primavera al pueblo, en el jardín del Gigante seguía el invierno; estaba lleno de escarcha y nieve. Los pájaros no cantaban y los árboles no tenían flor. El gigante estaba solo y malhumorado. Un día se apoyó en el alfeizar de su ventana, miró al jardín y se preguntó:

- ¿Por qué tarda tanto en llegar la primavera?

Ni la primavera ni el verano llegaban al castillo del Gigante egoísta.

Una mañana, después de mucho tiempo, el Gigante se despertó y oyó el trino de un pájaro. Era la melodía de un petirrojo. El Gigante se asomó y vio que la nieve había desaparecido.

- ¿Qué está pasando en mi jardín? ¡Creo que la primavera ha llegado por fin!

Entonces pudo ver que el niño había entrado en el jardín por un agujero. Estaba sentado al lado de una secuoya y todos los árboles estaban cubiertos de flores.

- iQué egoísta he sido! - dijo el Gigante.

El niño al ver la cara sonriente del Gigante se acercó a él y le preguntó:

- ¿Me puedo quedar a jugar en tu jardín?

El Gigante respondió afirmativamente y desde entonces, el niño juega en el jardín del Gigante. English translation of children's text:

\section{The selfish giant}

A child used to play in the Giant's garden. The garden was large and beautiful. In it, there were all kinds of trees: a fir tree, an orange tree, a redwood tree, a palm tree, a magnolia.... There was also a bird that used to stand on the trees and sang sweetly.

- How happy I am here! -cried the child.

One day, the Giant came to the castle and as he saw the boy he said:

- What are you doing here? Get out of my garden!

The child ran away and the giant closed the door of the castle garden.

When spring came to the village, in the garden of the Giant was still winter; it was covered in frost and snow. No birds were singing and the trees had no flower. The giant was alone and angry. One day, he leaned on the sill of the window, looked at the garden and wondered:

- Why does it take so long for the spring to arrive?

Neither spring nor summer arrived at the castle of the selfish Giant.

One morning, after a long time, the giant woke up and heard the song of a bird. It was the song of a robin. The Giant looked out and saw that the snow was gone. 
- What is happening in my garden? I think that spring has finally arrived!

Then, he saw that the boy had entered the garden through a hole. He sat next to a redwood, and all the trees were covered with flowers.

- How selfish I have been! - said the Giant.

The child, seeing the smiley face of the Giant, approached him and asked:

- $\quad$ Can I stay and play in your garden?

The Giant said yes, and since then, the child plays in the Giant's garden.

Spanish version of adults' text:

\section{Viaje a la luna}

En julio de 1969, el hombre llegó a la Luna. Ésta fue una de las ambiciones más importantes del ser humano. El Apolo 11 estaba tripulado por tres astronautas y cuatro días después de despegar de la Tierra, llegaron a la Luna. Dos de ellos, bajaron a explorar la superficie lunar, recorrieron el satélite durante unas horas, recogieron rocas y por último, clavaron la bandera de su país. El tercero de los astronautas se quedó en órbita realizando numerosos experimentos y fotos.

Viajar al espacio tiene que ser algo fascinante y eso es lo que nos cuenta en una carta uno de los astronautas. Cuando era niño sentía especial atracción por la Luna y siempre me decía:

- ¿Qué bonita es la luna!

- ¿Alguien la habrá visitado ya?

- ¿Quién pudiera viajar hasta ella!

- ¿Tendrá habitantes como la Tierra?

Todas las noches me asomaba a la ventana de mi habitación para contemplarla. Me fascinaba verla brillar a lo lejos. Al verla me hacía miles de preguntas acerca de ella y de la vida de los astronautas. Lo que nunca me imaginaba es que de mayor iba a ser astronauta.

La experiencia de visitar la Luna es indescriptible. La Luna es un lugar fascinante y geológicamente, una auténtica piedra preciosa. Pero, lo más sorprendente es que cuando me encontraba en la Luna, mis pensamientos se dirigían a la Tierra:

- ¿Cómo estará mi familia?

- ¿Podré regresar de nuevo a la Tierra?

- ¡Qué bonito es nuestro planeta!

- ¿Qué suerte poder vivir en un sitio tan maravilloso!

Sin duda, mi viaje a la Luna me hizo reflexionar sobre lo extraordinariamente afortunados que somos por tener aire para respirar, por poder vivir en la Tierra. Por ello, deberíamos de ser conscientes y proteger nuestro planeta.

English translation of adults' text: 


\section{Trip to the moon}

In July 1969, the man reached the moon. It was one of the major ambitions of mankind. Apollo 11 was manned by three astronauts, and 4 days after taking off from Earth, they reached the Moon. Two of them went down to explore the moon's surface, explored the satellite for a few hours, collected rocks and finally nailed the flag of their country. The third of the astronauts remained in orbit doing experiments and photos.

Travelling into space has to be a fascinating thing, and that's what one of the astronauts tells us in a letter. 'As a child, I felt a special attraction to the Moon and always told myself:

- How beautiful the moon is!

- Has someone already visited it?

- Who could travel to her!

- Will it have people like those on Earth?

Every night, I peeked out the window of my room to watch the moon. I was fascinated to see it, shining in the distance. Seeing it, I asked myself thousands of questions about it and the lives of astronauts. What I never imagined is that, as an adult, I would be an astronaut.

The experience of visiting the moon is indescribable. The Moon is a geologically fascinating place, a real gem. But, most surprising is that when I was on the moon, my thoughts turned to Earth:

- How my family would be?

- Will I be able to return to Earth?

- How beautiful is our planet!

- How lucky we are to live in such a wonderful place!

Definitely, my trip to the moon made me think about how extraordinarily lucky we are for having air to breathe, to have the opportunity to live on Earth. Therefore, we should be aware of it and protect our planet.'

Target sentences are in italics.

\section{References}

Afonso, O., Suárez-Coalla, P., \& Cuetos, F. (2015). Spelling impairments in Spanish dyslexic adults. Frontiers in Psychology, 6, 466. doi:10.3389/fpsyg.2015.00466.

Alves, L. M., Reis, C., \& Pinheiro, A. (2015). Prosody and reading in dyslexic children. Dyslexia, 21, 35-49. doi: $10.1002 /$ dys. 1485 .

Baqué, L., \& Estruch, M. (2003). Modelo de Aix-en-Provence. [Model of Aix-in-Provence]. In P. Prieto (Ed.), Teorías de la entonación. [Theories of intonation] (pp. 123-153). Barcelona: Ariel.

Barca, L., Burani, C., Di Filippo, G., \& Zoccolotti, P. (2006). Italian developmental dyslexic and proficient readers: where are the differences? Brain and Language, 98, 347-351. doi:10.1016/j.bandl.2006.05.001.

Benjamin, R. G., \& Schwanenflugel, P. J. (2010). Text complexity and oral reading prosody in young readers. Reading Research Quarterly, 45(4), 388-404. doi:10.1598/RRQ.45.4.2.

Binder, K. S., Tighe, E., Jiang, Y., Kaftanski, K., Qi, C., \& Ardoin, S. P. (2013). Reading expressively and understanding thoroughly: an examination of prosody in adults with low literacy. Reading and Writing: An Interdisciplinary Journal, 26(5), 665-680. doi:10.1007/s11145-012-9382-7.

Boersma, P., \& Weenink, D. (2011). Praat: doing phonetics by computer (Version 5.2.22) [Computer software]. Current version available: www.fon.hum.uva.nl/praat/ 
Breznitz, Z., \& Misra, M. (2003). Speed of processing of the visual-orthographic and auditory-phonological systems in adult dyslexics: the contribution of asynchrony to word recognition deficits. Brain and Language, 85(3), 486-502. doi:10.1016/S0093-934X(03)00071-3.

Bruck, M. (1990). Word-recognition skills of adults with childhood diagnoses of dyslexia. Developmental Psychology, 26(3), 439-454. doi:10.1037/0012-1649.26.3.439.

Bruck, M. (1992). Persistence of dyslexics' phonological awareness deficits. Developmental Psychology, 28(5), $874-886$.

Calet, N., Defior, S., \& Gutiérrez-Palma, N. (2013). A cross-sectional study of fluency and reading comprehension in Spanish primary school children. Journal of Research in Reading. doi:10.1111/1467-9817.12019.

Chafe, W. (1988). Punctuation and the prosody of written language. Written Communication, 5(4), 395-426. doi: $10.1177 / 0741088388005004001$.

Choi, J. Y. (2003). Pause length and speech rate as durational cues for prosody markers. Journal of the Acoustical Society of America, 114(4), 2395. doi:10.1121/1.4778053.

Cowie, R., Douglas-Cowie, E., \& Wichmann, A. (2002). Prosodic characteristics of skilled reading: fluency and expressiveness in 8-10 year old readers. Language and Speech, 45, 47-82. doi:10.1177/ 00238309020450010301.

Cromer, W. (1970). The difference model: a new explanation for some reading difficulties. Journal of Educational Psychology, 61(6), 471-483. doi:10.1037/h0030288.

Cuetos, R., Rodríguez, B., Ruano, E., \& Arribas, D. (2007). PROLEC-R. Batería de Evaluación de los Procesos Lectores, Revisada. [Battery for the Assessment of Reading Processes-Revised]. Madrid: TEA Ediciones.

Cuetos, F., \& Suarez-Coalla, P. (2009). From grapheme to word in reading acquisition in Spanish. Applied Psycholinguistics, 30(4), 583-601. doi:10.1017/S0142716409990038.

Davies, R., Rodríguez-Ferreiro, J., Suárez, P., \& Cuetos, F. (2013). Lexical and sub-lexical effects on accuracy, reaction time and response duration: impaired and typical word and pseudoword reading in a transparent orthography. Reading and Writing: An Interdisciplinary Journal, 26(5), 721-738. doi:10.1007/s11145-0129388-1.

De Luca, M., Pontillo, M., Primativo, S., Spinelli, D., \& Zoccolotti, P. (2013). The eye-voice lead during oral reading in developmental dyslexia. Frontiers in Human Neuroscience, 7, 1-17. doi:10.3389/fnhum.2013. 00696.

Dowhower, S. L. (1991). Speaking of prosody: Fluency's unattended bedfellow. Theory Into Practice, 30(3), 165-175. doi:10.1080/00405849109543497

Ehri, L., \& Saltmarsh, J. (1995). Beginning readers outperform older disabled readers in learning to read words by sight. Reading and Writing: An Interdisciplinary Journal, 7(3), 295-326. doi:10.1007/BF03162082.

Fernández Huerta, J. (1959). Medidas sencillas de lecturabilidad. [Simple measures of readability]. Consigna, 214, 29-32.

Fuchs, L., Fuchs, D., Hosp, M., \& Jenkins, J. (2001). Oral reading fluency as an indicator of reading competence: a theoretical, empirical, and historical analysis. Scientific Studies of Reading, 5(3), 239-256. doi:10.1207/ S1532799XSSR0503 3.

Garrido, J. M. (1990). Modelización de patrones melódicos del español para la síntesis y reconocimiento de habla. [Modelling of the Spanish melodic patterns for synthesis and speech recognition]. Departament de Filologia Espanyola Facultat de Lletres: Bralona.

Giménez, A., Luque, J. L., López-Zamora, M., \& Fernández-Navas, M. (2015). A self-report questionnaire on reading-writing difficulties for adults. Anales de Psicología, 31(1), 109-119. doi:10.6018/analesps.31.1. 166671.

Goldman Eisler, F. (1968). Experiments in spontaneous speech. London and New York: Academic Press. Psycholinguistics.

Grainger, J., Bouttevin, S., Truc, C., Bastien, M., \& Ziegler, J. (2003). Word superiority, pseudoword superiority, and learning to read: a comparison of dyslexic and normal readers. Brain and Language, 87(3), 432-440. doi:10.1016/S0093-934X(03)00145-7.

Grosjean, F., Grosjean, L., \& Lane, H. (1979). The patterns of silence: performance structures in sentence production. Cognitive Psychology, 11, 58-81. doi:10.1016/0010-0285(79)90004-5.

Hatcher, J., Snowling, M. J., \& Griffiths, Y. M. (2002). Cognitive assessment of dyslexic students in higher education. British Journal of Educational Psychology, 72(Pt 1), 119-133. doi:10.1348/000709902158801.

Jiménez, J., \& Alonso, M. L. (2005). Método para el desarrollo de la comprensión lectora [Method for development of reading comprehension]. Madrid: La Tierra Hoy, S.L.

Kame'enui, E. J., \& Simmons, D. C. (2001). Introduction to this special issue: the DNA of reading fluency. Scientific Studies of Reading, 5(3), 203-210.

Klauda, S. L., \& Guthrie, J. T. (2008). Relationships of three components of reading fluency to reading comprehension. Journal of Educational Psychology, 100, 310-321. doi:10.1037/0022-0663.100.2.310. 
Koriat, A., Greenberg, S., \& Kreiner, H. (2002). The extraction of structure during reading: evidence from reading prosody. Memory \& Cognition, 30(2), 270-280. doi:10.3758/BF03195288.

Kuhn, M. R., Schwanenflugel, P. J., \& Meisinger, E. B. (2010). Aligning theory and assessment of reading fluency: automaticity, prosody, and definitions of fluency. Reading Research Quarterly, 45(2), 230-251. doi: 10.1598/RRQ.45.2.4.

Kuhn, M. R., \& Stahl, S. A. (2003). Fluency: a review of developmental and remedial practices. Journal of Educational Psychology, 95, 3-21. doi:10.1037/0022-0663.95.1.3.

LaBerge, D., \& Samuels, S. J. (1974). Toward a theory of automatic information processing in reading. Cognitive Psychology, 95(1), 3-21. doi:10.1016/0010-0285(74)90015-2.

Leinonen, S., Müller, K., Leppänen, P. H. T., Aro, M., Ahonen, T., \& Lyytinen, H. (2001). Heterogeneity in adult dyslexic readers: relating processing skills to the speed and accuracy of oral text reading. Reading and Writing: An Interdisciplinary Journal, 14(3-4), 265-296. doi:10.1023/A:1011117620895.

Logan, G. D. (1997). Automaticity and reading: perspectives from the instance theory of automatization. Reading and Writing Quarterly: Overcoming Learning Disabilities, 13, 123-146. doi:10.1080/1057356970130203.

Manis, F. R. (1985). Acquisition of word identification skills in normal and disabled readers. Journal of Educational Psychology, 77(1), 78-90. doi:10.1037/0022-0663.77.1.78.

Martínez-Celdrán, E., \& Fernández-Planas, A. M. (2013). Manual de fonética española [Spanish phonetics manual]. E. Ariel: Barcelona.

Meyler, A. \& Breznitz, Z. (2003) Processing of phonological, orthographic and cross-modal word representations among adult dyslexic and normal readers. Reading and Writing: An Interdisciplinary Journal, 16, 785-803.

Miller, J., \& Schwanenflugel, P. J. (2006). Prosody of syntactically complex sentences in the oral reading of young children. Journal of Educational Psychology, 98(4), 839-843. doi:10.1037/0022-0663.98.4.839.

Miller, J., \& Schwanenflugel, P. J. (2008). A longitudinal study of the development of reading prosody as a dimension of oral reading fluency in early elementary school children. Reading Research Quarterly, 43(4), 336-354. doi:10.1598/RRQ.43.4.2.

National Institute of Child Health and Human Development. (2000). Report of the National Reading Panel. Teaching children to read: an evidence-based assessment of the scientific research literature on reading and its implications for reading instruction: reports of the subgroups (NIH Publication No. 00-4754). Washington: U.S. Government Printing Office.

Nergård-Nilssen, T., \& Hulme, C. (2014). Developmental dyslexia in adults: behavioural manifestations and cognitive correlates. Dyslexia, 20(3), 191-207. doi:10.1002/dys.1477.

O'Shea, L., \& Sindelar, P. (1983). The effects of segmenting written discourse on the reading comprehension of low- and high-performance readers. Reading Research Quarterly, 18(4), 458-465. doi:10.2307/ 747380 .

Ohala, J. J. (1978). The production of ton. In V. A. Fromkin (Ed.), Tone: a linguistic survey. Academic Press, pp. $5-39$.

Parrila, R., Georgiou, G., \& Corkett, J. (2007). University students with a significant history of reading difficulties: what is and is not compensated. Exceptionality Education Canada, 17, 195-220.

Perfetti, C. A., \& Hogaboam, T. (1975). Relationship between single word decoding and reading comprehension skill. Journal of Educational Psychology, 67(4), 461-469. doi:10.1037/h0077013.

Pikulski, J. J., \& Chard, D. J. (2005). Fluency: bridge between single word decoding and reading comprehension. The Reading Teacher, 58(6), 510-519.

Prieto, P., D’Imperio, M., Elordieta, G., Frota, S., \& Vigário, M. (2006). Evidence for soft preplanning in tonal production: initial scaling in Romance. In R. Hoffmann \& H. Mixdorff (Eds.), Proceedings of speech prosody (pp. 803-806). Dresden: TUDpress Verlag der Wissenschaften GmbH.

Rack, J. P., Snowling, M. J., \& Olson, R. K. (1992). The nonword reading deficit in developmental dyslexia: a review. Reading Research Quarterly, 27(1), 28-53. doi:10.2307/747832.

Ramos, J. L., \& Cuetos, F. (2005). PROLEC-SE: Evaluación de los procesos lectores [Battery for the assessment of reading processes]. Madrid: TEA Ediciones.

Rasinski, T., Rikli, A., \& Johnston, S. (2009). Reading fluency: more than automaticity? More than a concern for the primary grades? Literacy Research and Instruction, 48(4), 350-361. doi:10.1080/19388070802468715.

Ravid, D., \& Mashraki, Y. E. (2007). Prosodic reading, reading comprehension and morphological skills in Hebrew-speaking fourth graders. Journal of Research in Reading, 30(2), 140-156. doi:10.1111/j.1467-9817. 2007.00340.x.

Reitsma, P. (1983). Printed word learning in beginning readers. Journal of Experimental Child Psychology, 36(2), 321-339. doi:10.1016/0022-0965(83)90036-X.

Schwanenflugel, P. J., Hamilton, A. M., Kuhn, M. R., Wisenbaker, J. M., \& Stahl, S. A. (2004). Becoming a fluent reader: reading skill and prosodic features in the oral reading of young readers. Journal of Educational Psychology, 96, 119-129. doi:10.1037/0022-0663.96.1.119. 
Schwanenflugel, P. J., Meisinger, E. L., Wisenbaker, J. M., Kuhn, M. R., Strauss, G. P., \& Morris, R. D. (2006). Becoming a fluent and automatic reader in the early elementary school years. Reading Research Quarterly, 41(4), 496-522. doi:10.1598/RRQ.41.4.4.

Schwanenflugel, P. J., Westmoreland, M. R., \& Benjamin, R. G. (2013). Reading fluency skill and the prosodic marking of linguistic focus. Reading and Writing. doi:10.1007/s11145-013-9456-1.

Shaywitz, S. E., Fletcher, J. M., Holahan, J. M., Shneider, A. E., Marchione, K. E., Stuebing, K. K., et al. (1999). Persistence of dyslexia: the Connecticut Longitudinal Study at adolescence. Pediatrics, 104(6), 1351-1359. doi:10.1542/peds.104.6.1351.

Snowling, M., Muter, V., \& Carroll, J. (2007). Children at family risk of dyslexia: a follow-up in early adolescence. Journal of Child Psychology and Psychiatry, 48(6), 609-618. doi:10.1111/j.1469-7610.2006. 01725.x.

Suárez-Coalla, P., \& Cuetos, F. (2012). Reading strategies in Spanish developmental dyslexics. Annals of Dyslexia, 62(2), 71-81. doi:10.1007/s11881-011-0064-y.

Suárez-Coalla, P., \& Cuetos, F. (2015). Reading difficulties in Spanish adults with dyslexia. Annals of Dyslexia, 65(1), 33-51. doi:10.1007/s11881-015-0101-3.

Suárez-Coalla, P., Ramos, S., Álvarez-Cañizo, M., \& Cuetos, F. (2014). Orthographic learning in dyslexic Spanish children. Annals of Dyslexia, 64(2), 166-181. doi:10.1007/s11881-014-0092-5.

Swanson, L., \& Hsieh, C. J. (2009). Reading disabilities in adults: a selective meta-analysis of the literature. Review of Educational Research, 79, 1362-1390. doi:10.3102/0034654309350931.

Szenkovits, G., \& Ramus, F. (2005). Exploring dyslexics' phonological deficit I: lexical vs sub-lexical and input vs output processes. Dyslexia, 11(4), 253-268. doi:10.1002/dys.308.

Szigriszt-Pazos, F. (1993). Sistemas predictivos de legibilidad del mensaje escrito: Fórmula de perspicuidad. [Readability predictive systems of the written message: Formula perspicuity]. Tesis doctoral. Universidad Complutense de Madrid. http://biblioteca.ucm.es/tesis/19911996/S/3/S3019601.pdf

Tøndering, J. (2011). Preplanning of intonation in spontaneous versus read aloud speech: evidence from Danish. Proceedings of ICPhS XVII, 2010-2013.

Tops, W., Callens, M., Lammertyn, J., Van Hees, V., \& Brysbaert, M. (2012). Identifying students with dyslexia in higher education. Annals of Dyslexia, 62(3), 186-203. doi:10.1007/s11881-012-0072-6.

Umeda, N. (1982). "F0 declination" is situation dependent. Journal of Phonetics, 10, 279-290.

Undheim, A. M. (2009). A thirteen-year follow-up study of young Norwegian adults with dyslexia in childhood: reading development and educational levels. Dyslexia, 15(4), 291-303. doi:10.1002/dys.384.

Vaissière, J. (1983). Language-independent prosodic features. In A. Cutler \& D. R. Ladd (Eds.), Prosody: models and measurements (pp. 53-66). Berlin: Springer-Verlag.

Walczyk, J., Marsiglia, C. S., Johns, A. J., \& Bryan, K. S. (2004). Children's compensations for poorly automated reading skills. Discourse Processes, 37, 47-66. doi:10.1207/s15326950dp3701_3.

Wechsler, D. (1981). Escala de Inteligencia para Adultos-Revisión. [Intelligence scäle for adults-revised]. New York: Psychological Corporation.

Wechsler, D. (2001). Escala de Inteligencia para Niños-Revisión. [Intelligence scale for children-revised]. New York: Psychological Corporation.

Wimmer, H. (1993). Characteristics of developmental dyslexia in a regular writing system. Applied Psycholinguistics, 14, 1-33. doi:10.1017/S0142716400010122.

Wolf, M., \& Katzir-Cohen, T. (2001). Reading fluency and its intervention. Scientific Studies of Reading, 5(3), 211-239. doi:10.1207/S1532799XSSR0503 2.

Ziegler, J. C., Perry, C., Ma-Wyatt, A., Ladner, D., \& Schulte-Korne, G. (2003). Developmental dyslexia in different languages: language-specific or universal? Journal of Experimental Child Psychology, 86(3), 169193. doi:10.1016/S0022-0965(03)00139-5. 